\title{
Kinerja Saluran Drainase Terhadap Genangan Air Pada Bahu Jalan D. I. Panjaitan Menuju Bundaran Pesawat Lepo-Lepo
}

\author{
Fathur Rahman Rustan ${ }^{1}$, Erika Aprianti ${ }^{2}$, Ahmad Taufik Abdullah $^{3}$, Retno Puspaningtyas ${ }^{4}$ \\ 1,4 Program Studi Teknik Sipil, Universitas Sembilanbelas November Kolaka, 93517 \\ ${ }^{2,3}$ Program Studi D-III Teknik Sipil, Program Pendidikan Vokasi, Universitas Halu Oleo, 93232 \\ E-mail :ur_mantan@usn.ac.id
}

\begin{abstract}
ABSTRAK
Wilayah kelurahan Wundudopi tepatnya pada ruas jalan D. I. Panjaitan menuju sekitar Bundaran Pesawat Kota Kendari mempunyai persoalan kinerja saluran drainase yang menyebabkan adanya genangan air pada bahu maupun badan jalan yang dapat mengganggu aktivitas masyarakat serta arus lalu lintas di saat musim hujan. Tujuan dari penelitian ini adalah untuk menganalisis kinerja saluran drainase terhadap genangan air pada bahu jalan di kelurahan Wundudopi. Dalam menganalisis kinerja saluran drainase dilakukan analisis frekuensi dan probabilitas dengan berbagai kala ulang hujan menggunakan metode Distribusi Normal, Log Normal, Log-Person III, dan Gumbel serta analisis kapasitas tampung saluran yang dilakukan berdasarkan debit rencana, kemudian di dapatkan dimensi saluran rencana dan kapasitas tampungnya. Setelah itu, kapasitas tampung saluran drainase rencana kemudian dibandingkan dengan kapasitas tampung saluran eksisting berdasarkan dimensi saluran eksisting yang ada. Berdasarkan perhitungan dan kondisi eksisting di lapangan diperoleh hasil bahwa saluran drainase yang nilai kapasitas tampung saluran rencananya lebih besar dibandingkan kapasitas tampung saluran eksisting yaitu: S5. Selain persoalan kapasitas tampung saluran ada beberapa faktor yang menjadi penyebab adanya genangan air yaitu: pola aliran, sistem gorong-gorong, sedimentasi, sampah, rerumputan, dan dimensi yang rusak. Diperlukan solusi terhadap permasalahan yang ada dengan cara perubahan dimensi saluran, dan adanya normalisasi saluran secara berkala.
\end{abstract}

Kata Kunci: Kinerja Saluran Drainase, Genangan Air, Bahu Jalan

\section{PENDAHULUAN}

Drainase secara umum didefinisikan sebagai usaha mengalirkan air yang berlebihan dalam suatu konteks pemanfaatan tertentu. Dalam bidang teknik sipil, drainase secara umum didefinisikan sebagai salah satu tindakan teknis untuk mengurangi kelebihan air, baik yang berasal dari air hujan, rembesan, maupun kelebihan air dari suatu kawasan atau lahan. Jika dalam penanganan drainase kurang baik, maka akan mengakibatkan terjadinya genangan air pada daerah sekitar saluran drainase tersebut. Permasalahan terkait dengan saluran drainase yang kurang baik banyak terjadi di kota-kota besar khususnya di Kota Kendari.

Baruga salah satu kecamatan di Kota Kendari, Provinsi Sulawesi Tenggara dengan luas wilayah $\pm 49.15 \mathrm{~km} 2$, terdiri dari 4 Kelurahan. Dilihat dari letak astronomi terletak pada 3'59'47' dan 45'01" Lintang Selatan (LS) dan membentang dari Barat ke Timur di antara $122^{\circ} 26^{\prime} 37^{\prime \prime}$ dan $122^{\circ} 32^{\prime} 57^{\prime}$ ' Bujur Timur (BT). Sebagaimana daerah-daerah lain di Indonesia, Kota Kendari hanya mengenal dua musim yakni musim kemarau dan musim hujan. Keadaan musim ini sangat dipengaruhi oleh arus angin yang bertiup di atas wilayahnya. Perbedaan ketinggian dari permukaan laut, daerah pegunungan dan daerah pesisir mengakibatkan sedikit perbedaan keadaan suhu udara untuk masing-masing tempat dalam suatu kawasan/wilayah. Secara keseluruhan, wilayah kota Kendari merupakan daerah bersuhu tropis.

Dengan intensitas curah hujan yang tinggi serta kondisi saluran drainase khususnya di kecamatan Baruga yang kurang baik dapat menyebabkan berbagai persoalan timbul yang nantinya akan merusak infrastruktur yang sudah ada. Kinerja saluran drainase di kecamatan Baruga, dinilai masih belum baik. Hal ini dapat terlihat dengan masih banyaknya daerah genangan air ketika terjadi hujan dengan intensitas tinggi. Artinya, fungsi dari sistem saluran drainase dalam mengalirkan air hujan ataupun genangan belum bekerja dengan baik.

Sejak beberapa bulan terakhir, sering terdapat genangan air di beberapa titik di kecamatan Baruga, salah satunya adalah wilayah kelurahan Wundudopi tepatnya pada ruas jalan D. I. Panjaitan menuju sekitar Bundaran Pesawat Kota Kendari. Hal ini menyebabkan ketidaknyamanan masyarakat pada saat melintasi jalan tersebut, selain itu dapat menyebabkan terancamnya permukiman warga sekitar dan infrastruktur perekonomian yang sudah ada. Oleh karena itu, perlu diadakan suatu analisa terkait dengan kinerja saluran drainase serta faktor-faktor penyebab terjadinya genangan air pada lokasi yang dimaksud. 


\section{TINJAUAN PUSTAKA}

\subsection{Pengertian Drainase Perkotaan}

Merujuk referensi [1], Drainase berasal dari bahasa Inggris "drainage" yang mempunyai arti mengalirkan, menguras, membuang, atau mengalihkan air. Secara umum, sistem drainase dapat didefinisikan sebagai serangkaian bangunan air yang berfungsi untuk mengurangi dan atau membuang kelebihan air dari suatu kawasan atau lahan, sehingga lahan dapat difungsikan secara optimal. Sistem drainase terdiri dari saluran penerima (interceptor drain), saluran pengumpul (collector drain), saluran pembawa (conveyor drain), saluran induk (main drain) dan bagian penerima air (receiving waters).

Drainase perkotaan/terapan merupakan sistem pengeringan dan pengaliran air dari wilayah perkotaan yang meliputi :

1. Permukiman;

2. Kawasan industri dan perdagangan;

3. Kampus dan sekolah;

4. Rumah sakit dan fasilitas umum;

5. Lapangan olahraga;

6. Lapangan parkir;

7. Instalasi militer, listrik, telekomunikasi;

8. Pelabuhan udara.

Kriteria desain drainase perkotaan memiliki kekhususan, sebab untuk perkotaan ada tambahan variabel desain seperti :

1. Keterkaitan dengan tata guna lahan;

2. Keterkaitan dengan masterplan drainase kota;

3. Keterkaitan dengan masalah sosial budaya [2]

\subsection{Drainase Menanggulangi Genangan Banjir}

Di musim penghujan di Indonesia dan negara didunia selalu dilanda banjir. Banjir yang menyebabkan genangan ini sebagai akibat dari curah hujan dan intensitas hujan yang tinggi.

Pada umumnya banjir diakibatkan oleh beberapa faktor antara lain :

1. Banjir akibat air laut pasang;

Kota dengan lokasi di tepi pantai jika air laut pasang, maka umumnya air akan menggenangi area pantai. Jika alat-alat sistem drainase kota berfungsi dengan baik, pada waktu air laut surut genangan akan tertanggulangi.

2. Banjir akibat kota dilanda hujan.

a. Jika area kota di tepi pantai dilanda hujan dengan curah hujan dan intensitas hujan sangat tinggi yang umumnya terjadi pada waktu musim hujan, jika air laut sedang atau menjelang surut dan sistem drainase berfungsi dengan baik, air hujan akan segera mengalir ke laut dengan baik dan jika air laut sedang pasang akan terjadi genangan sementara sampai air laut surut.

b. Jika kota di area dataran dilanda hujan dengan curah hujan dan intensitas hujan sangat tinggi yang umumnya terjadi pada saat musim hujan, jika sistem drainase berfungsi dengan baik, air hujan akan mengalir melalui saluran drainase dan air meresap ke dalam tanah di area terbuka di perkotaan dan ke dalam sumur-sumur peresapan.

c. Jika kota di area tepi pantai atau di area dataran dilanda hujan dengan curah hujan dan intensitas yang sangat tinggi, mendapat aliran air kiriman dari sisi atas kota dengan dataran yang lebih tinggi, kota akan mendapatkan banjir kiriman. Jika kota tidak dilintasi sungai, air akan mengalir di area kota, akan menggenangi dan membanjiri kota, sedangkan kota yang dilintasi sungai maka aliran air akan mengalir ke dalam sungai dan jika sungai tidak dapat menampung volume banjir, akan terjadi genangan dan banjir [2].

\subsection{Analisis Frekuensi dan Probabilitas}

Dalam ilmu statistik dikenal beberapa macam distribusi frekuensi dan empat jenis distribusi yang banyak digunakan dalam bidang hidrologi adalah: (a) Distribusi Normal, (b) Distribusi Log Normal, (c) Distribusi Log-Person III, (d) Distribusi Gumbel dengan menggunakan berbagai kala ulang hujan (T) 2 tahun, 5 tahun, 10 tahun, 25 tahun, 50 tahun, dan 100 tahun.

Dalam statistik dikenal beberapa parameter yang berkaitan dengan analisis data yang meliputi rata-rata, simpangan baku, koefisien variasi, dan koefisien skewness (kecondongan atau kemencengan). 
Tabel 1. Parameter statistik yang penting

\begin{tabular}{cc}
\hline Parameter & Sampel \\
\hline Rata - rata & $\overline{\mathrm{X}}=\frac{1}{\mathrm{n}} \cdot \sum_{\mathrm{i}=1}^{\mathrm{n}} \mathrm{X}_{\mathrm{i}}$ \\
Simpangan baku & $\mathrm{S}=\left[\frac{1}{\mathrm{n}-1} \cdot \sum_{\mathrm{i}=1}^{\mathrm{n}}\left(\mathrm{X}_{\mathrm{i}}-\overline{\mathrm{X}}\right)^{2}\right]^{\frac{1}{2}}$ \\
Koefisien variasi/keragaman & $\mathrm{C}_{v}=\frac{\mathrm{s}}{\overline{\mathrm{X}}}$ \\
Koefisien skewness & $\mathrm{C}_{\mathrm{s}}=\frac{\mathrm{n} \cdot \sum_{\mathrm{i}=1}^{\mathrm{n}}\left(\mathrm{X}_{\mathrm{i}}-\overline{\mathrm{X}}\right)^{3}}{(\mathrm{n}-1) \cdot(\mathrm{n}-2) \cdot \mathrm{S}^{3}}$ \\
Koefisien kurtosius & $\mathrm{C}_{k}=\frac{\mathrm{n}^{2} \cdot \sum_{\mathrm{i}=1}^{\mathrm{n}}\left(\mathrm{X}_{\mathrm{i}}-\overline{\mathrm{X}}\right)^{4}}{(\mathrm{n}-1) \cdot(\mathrm{n}-2) \cdot(\mathrm{n}-3) \cdot \mathrm{S}^{4}}$ \\
\hline
\end{tabular}

\subsubsection{Distribusi Normal}

Distribusi normal atau kurva normal disebut pula distribusi Gauss. Fungsi densitas peluang normal (PDF = probability density function) yang paling dikenal adalah bentuk bell dan dikenal sebagai distribusi normal. Rumus-rumus distribusi normal dapat didekati dengan :

$$
\mathrm{X}_{\mathrm{T}}=\overline{\mathrm{X}}+\mathrm{K}_{\mathrm{T}} \cdot \mathrm{S}
$$

keterangan :

$\mathrm{X}_{\mathrm{T}}=$ Perkiraan nilai yang diharapkan terjadi dengan periode ulang $\mathrm{T}$-tahunan;

$\overline{\mathrm{X}}=$ Nilai rata-rata hitungan variat $\left(\mathrm{X}_{\mathrm{i}}\right)$;

$\mathrm{S}=$ Deviasi standar nilai variat;

$\mathrm{K}_{\mathrm{T}}=$ Faktor frekuensi, nilainya bergantung dari T. Nilai koefisien untuk distribusi Normal berdasarkan nilai variabel reduksi Gauss (variable reduced Gauss) dapat dilihat pada tabel 2.

Tabel 2. Nilai variabel reduksi Gauss

\begin{tabular}{ccccccc}
\hline \multicolumn{8}{c}{ Tabel 2. Nilai variabel reduksi Gauss } \\
\hline \multicolumn{7}{c}{ Periode Ulang, T (tahun) } \\
\hline $\mathbf{n}$ & 2 & 5 & 10 & 25 & 50 & 100 \\
$\mathbf{K}_{\mathbf{T}}$ & 0.00 & 0.84 & 1.28 & 1.71 & 2.05 & 2.33 \\
\hline
\end{tabular}

\subsubsection{Distribusi Log Normal}

Jika variabel acak $Y=\log X$ terdistribusi secara normal, maka X dikatakan mengikuti distribusi Log Normal. PDF (probability density function) untuk distribusi Log Normal dapat dituliskan dalam bentuk:

$$
\log X_{T}=\log \bar{X}+K_{T} \cdot S
$$

keterangan :

$\log X_{\mathrm{T}}=$ Nilai logaritma hujan rencana dengan periode ulang $\mathrm{T}$;

$\log \bar{X}=$ Nilai rata-rata logaritma;

$$
\log \bar{X}=\frac{\sum_{i=1}^{n} \log X_{i}}{n}
$$

$\mathrm{n} \quad=$ Lama pengamatan;

$\log X_{i}=$ Nilai logaritma curah hujan;

$\mathrm{S} \quad=$ Standar deviasi;

$$
\mathrm{S}=\sqrt{\frac{\sum_{\mathrm{i}=1}^{\mathrm{n}}\left(\log \mathrm{X}_{\mathrm{i}}-\log \overline{\mathrm{X}}\right)^{2}}{\mathrm{n}-1}}
$$

$\mathrm{K}_{\mathrm{T}} \quad=$ Faktor frekuensi, nilainya bergantung dari T. Nilai koefisien untuk distribusi Normal berdasarkan nilai variabel reduksi Gauss (variable reduced Gauss) dapat dilihat pada tabel 2;

$\mathrm{C}_{s} \quad=$ Koefisien skewness; 


$$
\mathrm{C}_{s}=\frac{\mathrm{n} \cdot \sum\left(\log \mathrm{X}_{\mathrm{i}}-\log \overline{\mathrm{X}}\right)^{3}}{(\mathrm{n}-1) \cdot(\mathrm{n}-2) \cdot \mathrm{S}^{3}}
$$

$\mathrm{C}_{k}=$ Koefisien kurtosius;

$$
\mathrm{C}_{k}=\frac{\mathrm{n}^{2} \cdot \sum\left(\log \mathrm{X}_{\mathrm{i}}-\log \overline{\mathrm{X}}\right)^{4}}{(\mathrm{n}-1) \cdot(\mathrm{n}-2) \cdot(\mathrm{n}-3) \cdot \mathrm{S}^{4}}
$$

$\mathrm{C}_{v}=$ Koefisien keragaman.

$$
\mathrm{C}_{v}=\frac{\mathrm{S}}{\log \overline{\mathrm{X}}}
$$

\subsubsection{Distribusi Log-Person III}

Salah satu distribusi dari serangkaian distribusi yang dikembangkan Person yang menjadi perhatian ahli sumber daya air adalah Log-Person Type III (LP.III). Hitung logaritma hujan atau banjir dengan periode ulang T dengan rumus:

$$
\log X_{T}=\log \bar{X}+K \cdot S
$$

keterangan :

$\log \mathrm{X}_{\mathrm{T}}=$ Nilai logaritma hujan rencana dengan periode ulang $\mathrm{T}$;

$\log \bar{X}=$ Nilai rata-rata logaritma curah hujan (gunakan persamaan 8);

$\mathrm{S} \quad=$ Standar deviasi (gunakan persamaan 9);

$\mathrm{C}_{s} \quad=$ Koefisien skewness (gunakan persamaan 10);

$\mathrm{C}_{k} \quad=$ Koefisien kurtosius (gunakan persamaan 11);

$\mathrm{C}_{v} \quad=$ Koefisien keragaman (gunakan persamaan 12$) ;$

$\mathrm{K}=$ Variabel standar (standardized variable) untuk X yang besarnya tergantung koefisien skewness. Harga $\mathrm{K}$ untuk berbagai nilai koefisien skewness dapat dilihat pada rujukan [3].

\subsubsection{Distribusi Gumbel}

Gumbel menggunakan harga ekstrem untuk menunjukkan bahwa dalam deret harga-harga ekstrem mempunyai fungsi distribusi eksponensial ganda. Apabila jumlah populasi yang terbatas (sampel), maka dapat didekati dengan persamaan:

$$
X_{T}=\bar{X}+S \cdot K
$$

keterangan :

$\mathrm{X}_{\mathrm{T}}=$ Hujan rencana atau debit dengan periode ulang $\mathrm{T}$;

$\overline{\mathrm{X}}=$ Nilai rata-rata sampel;

$\mathrm{S}=$ Standar deviasi (simpangan baku) sampel (gunakan persamaan 2);

$\mathrm{K}=$ Faktor probabilitas untuk harga-harga ekstrem Gumbel;

$$
\mathrm{K}=\frac{\mathrm{Y}_{\mathrm{T}_{\mathrm{r}}} \cdot \mathrm{Y}_{\mathrm{n}}}{\mathrm{S}_{\mathrm{n}}}
$$

$\mathrm{Y}_{\mathrm{T}_{\mathrm{r}}}=$ Reduced variated, yang dapat dihitung dengan persamaan berikut ini:

$$
\mathrm{Y}_{\mathrm{T}_{\mathrm{r}}}=-\ln \left\{-\ln \frac{T_{r}-1}{T_{r}}\right\}
$$

$\mathrm{Y}_{\mathrm{n}}=$ Reduced mean yang bergantung jumlah sampel/data $\mathrm{n}$;

$\mathrm{S}_{\mathrm{n}} \quad=$ Reduced standard deviation yang juga tergantung pada jumlah sampel/data $\mathrm{n}$;

$\mathrm{T}_{\mathrm{r}} \quad=$ Periode ulang (tahun).

\subsection{Penentuan Jenis Distribusi}

Penentuan jenis distribusi yang sesuai dengan data dilakukan dengan mencocokkan parameter statistik dengan syarat masingmasing jenis distribusi [3]. 
Tabel 3. Parameter statistik untuk menentukan jenis distribusi

\begin{tabular}{ccc}
\hline No. & Distribusi & Persyaratan \\
\hline 1. & Normal & $\mathrm{C}_{s} \approx 0$ \\
$\mathrm{C}_{k} \approx 3$
\end{tabular}

\subsection{Pengujian Kecocokan}

Diperlukan penguji parameter untuk menguji kecocokan (the goodness of fittest test) distribusi frekuensi sampel data terhadap fungsi peluang yang diperkirakan dapat menggambarkan atau mewakili distribusi frekuensi tersebut. Pengujian parameter yang sering dipakai adalah (1) Chi-Kuadrat, dan (2) Smirnov-Kolmogorov.

\subsection{Intensitas Curah Hujan}

Intensitas hujan adalah yang dinyatakan dalam tinggi hujan atau volume hujan tiap satuan waktu. Nilai intensitas hujan tergantung lama curah hujan dan frekuensi hujan dan waktu konsentrasi. Intensitas hujan dianalisis dari data hujan secara empiris atau secara statistik. Kurva intensitas hujan rencana, jika yang tersedia adalah hujan harian, dapat ditentukan dengan Metode Mononobe. Bentuk umum dari Rumus Mononobe adalah :

$$
I=\frac{R_{24}}{24} \cdot\left(\frac{24}{T}\right)^{2 / 3}
$$

I = Intensitas hujan rencana $(\mathrm{mm} / \mathrm{jam})$;

$\mathrm{R}_{24}=$ Curah hujan maksimum harian dalam 24 jam (mm);

$\mathrm{T}=$ Durasi hujan atau waktu konsentrasi (jam).[4], [5]

\subsection{Perkiraan Laju Aliran Puncak}

Ada beberapa metode untuk memperkirakan laju aliran puncak (debit banjir). Metode yang dipakai pada suatu lokasi lebih banyak ditentukan oleh ketersediaan data. Metode untuk memperkirakan laju aliran permukaan puncak yang umum dipakai adalah metode Rasional USSCS (1973). Persamaan matematik metode Rasional [6] dinyatakan dalam bentuk:

$$
\mathrm{Q}_{\mathrm{p}}=0,00278 \cdot \mathrm{C} \cdot \mathrm{I} \cdot \mathrm{A}
$$

Di mana $\mathrm{Q}_{\mathrm{p}}$ adalah debit puncak banjir dalam $\mathrm{m}^{3} /$ detik, $\mathrm{C}$ adalah koefisien limpasan, I adalah intensitas hujan selama waktu konsentrasi dalam $\mathrm{mm} / \mathrm{jam}$ dan A adalah luas daerah aliran dalam hektar.

Jika suatu daerah aliran terdiri atas berbagai macam tata guna lahan dengan koefisien pengaliran yang berbeda-beda, maka nilai C dapat dihitung dengan persamaan 19

keterangan :

$$
\mathrm{C}=\frac{\sum_{\mathrm{i}=1}^{\mathrm{n}} \mathrm{C}_{\mathrm{i}} \cdot \mathrm{A}_{\mathrm{i}}}{\sum_{\mathrm{i}=1}^{\mathrm{n}} \mathrm{C}_{\mathrm{i}}}
$$

$\mathrm{C}_{\mathrm{i}}$ : Koefisien limpasan jenis penutup tanah $\mathrm{i}$;

$\mathrm{A}_{\mathrm{i}}$ : Luas lahan dengan jenis penutup tanah i (ha);

$\mathrm{n}$ : Jumlah jenis penutup lahan.

\subsection{Bentuk Saluran yang Paling Ekonomis}

Potongan melintang saluran yang paling ekonomis adalah saluran yang dapat melewatkan debit maksimum untuk luas penampang basah, kekasaran, dan kemiringan dasar tertentu. Berdasarkan persamaan kontinuitas, tampak jelas bahwa untuk luas penampang melintang tetap, debit maksimum dicapai jika kecepatan aliran maksimum. Bentuk penampang saluran ini mengacu pada pedoman Standar Nasional Indonesia (SNI 03-3424-1994). Bentuk saluran yang umum digunakan di lapangan yaitu bentuk trapesium. Adapun persamaan-persamaan yang digunakan adalah:

$$
\begin{aligned}
& A=(b+m \cdot h) \cdot h \\
& P=b+2 h \sqrt{1+m^{2}}
\end{aligned}
$$




$$
\mathrm{R}=\frac{\mathrm{A}}{\mathrm{P}}
$$

keterangan :

$A$ : Luas tampang basah saluran $\left(\mathrm{m}^{2}\right)$

$P$ : Keliling tampang basah saluran

$R$ : Jari-jari hidrolik (m)

$b$ : Lebar dasar saluran (m)

$h$ : Tinggi air normal di saluran (m)

$m$ : Kemiringan tebing saluran (m)

Sumber rujukan [7], [8], menyatakan bahwa penampang trapesium yang paling efisien adalah jika kemiringan dindingnya, $\mathrm{m}=$ $\frac{1}{\sqrt{3}}$ atau $\theta=60^{\circ}$, Trapesium yang terbentuk berupa setengah segienam beraturan (heksagonal) dan didapatkan persamaannya adalah sebagai berikut :

$$
\begin{aligned}
& A=h^{2} \sqrt{3} \\
& P=2 h \sqrt{3}
\end{aligned}
$$

$$
\begin{aligned}
\mathrm{R} & =\frac{h}{2} \\
\mathrm{~b} & =\frac{2}{3} \mathrm{~h} \sqrt{3}
\end{aligned}
$$

\section{METODE}

\subsection{Lokasi Penelitian}

Penelitian ini dilakukan pada ruas jalan D. I. Pandjaitan menuju ke bundaran pesawat Lepo-Lepo, Kel. Wundudopi, Kec. Baruga, Kota Kendari, Provinsi Sulawesi Tenggara. Lokasi ini merupakan langganan banjir setiap kali turun hujan. Adapun gambar untuk lokasi penelitian dapat dilihat pada Gambar 1 dengan arah tinjauan aliran air mengalir dari saluran S1 menuju saluran S5 serta foto terjadinya genangan air ditunjukkan pada Gambar 2 dan 3.

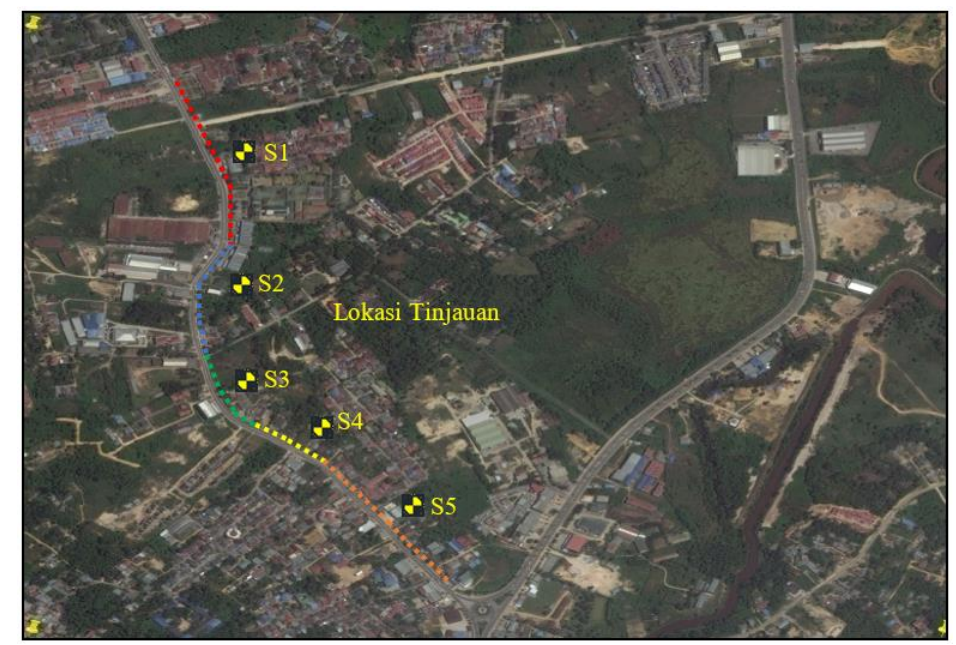

Gambar 1. Lokasi Penelitian

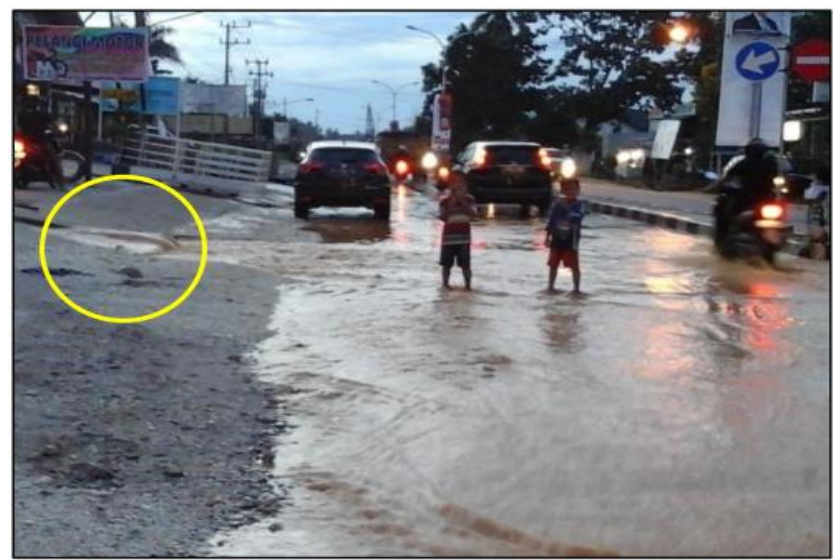

Gambar 2. Salah satu titik terjadinya luapan air 


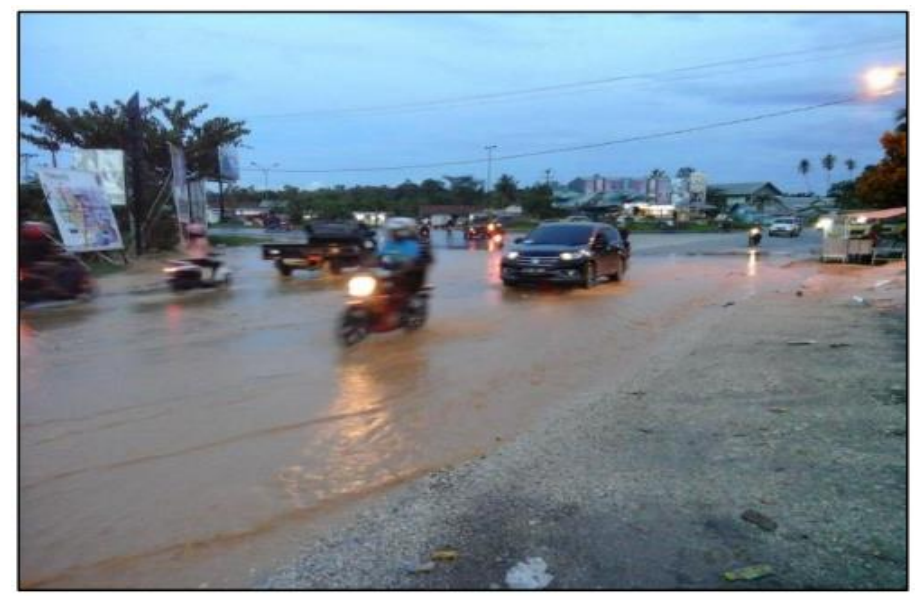

Gambar 3. Titik luapan air area Bundaran Pesawat

\subsection{Teknik Analisis Data}

Dalam menganalisis kinerja saluran terhadap genangan air, maka dilakukan tahapan-tahapan sebagai berikut:

a) Analisis frekuensi dan probabilitas;

b) Penentuan jenis distribusi;

c) Pengujian kecocokan;

d) Perkiraan laju aliran puncak;

e) Perhitungan saluran yang paling ekonomis;

f) Analisis kapasitas tampung saluran dengan membandingkan antara saluran drainase rencana dan saluran drainase eksisting.

\section{HASIL DAN PEMBAHASAN}

\subsection{Analisis Distribusi Probabilitas}

Dalam analisis distribusi probabilitas, data curah hujan yang digunakan adalah data tahun 2002 sampai tahun 2016 pada Stasiun Kota Kendari dan diperoleh dari Balai Wilayah Sungai Sulawesi IV Provinsi Sulawesi Tenggara. Data curah hujan periode 2002 - 2016 digunakan karena pada saat penelitian ini dilakukan hanya periode data tersebut yang tersedia dari pihak kantor penyedia data. Adapun data curah hujan maksimum yang diperoleh adalah sebagai berikut :

Tabel 4. Data Curah Hujan Maksimum

\begin{tabular}{cc}
\hline Tahun & Curah Hujan Maksimum Xi (mm) \\
\hline 2002 & 69.0 \\
2003 & 67.0 \\
2004 & 62.0 \\
2005 & 63.0 \\
2006 & 48.0 \\
2007 & 42.0 \\
2008 & 42.0 \\
2009 & 94.0 \\
2010 & 54.5 \\
2011 & 38.2 \\
2012 & 93.0 \\
2013 & 117.0 \\
2014 & 92.0 \\
2015 & 65.0 \\
2016 & 76.0 \\
\hline
\end{tabular}

Penentuan jenis sebaran data yang akan digunakan maka terlebih dahulu dilakukan analisis parameter statistik. Setelah dilakukan analisis parameter statistik, dilanjutkan dengan menganalisis distribusi probabilitas menggunakan beberapa metode. 


\subsubsection{Distribusi Normal}

Tabel 5. Rekapitulasi Curah Hujan Rencana Metode Normal

\begin{tabular}{ccccc}
\hline $\begin{array}{c}\mathbf{T} \\
(\text { tahun })\end{array}$ & $\begin{array}{c}\overline{\mathbf{X}} \\
(\mathbf{m m})\end{array}$ & $\mathbf{S}$ & $\mathbf{K}_{\mathbf{T}}$ & $\begin{array}{c}\mathbf{X}_{\mathbf{T}} \\
(\mathbf{m m})\end{array}$ \\
\hline 2 & & & 0.00 & 68.180 \\
5 & & & 0.84 & 87.277 \\
10 & 68.180 & 22.734 & 1.28 & 97.280 \\
25 & & & 1.71 & 107.055 \\
50 & & & 2.05 & 114.785 \\
\hline
\end{tabular}

\subsubsection{Distribusi Log Normal}

Tabel 6. Rekapitulasi Curah Hujan Rencana Metode Log Normal

\begin{tabular}{cccccc}
\hline $\begin{array}{c}\mathbf{T} \\
(\mathbf{t a h u n})\end{array}$ & $\begin{array}{c}\mathbf{L o g} \overline{\mathbf{X}} \\
(\mathbf{m m})\end{array}$ & $\mathbf{S}$ & $\mathbf{K}_{\mathbf{T}}$ & $\begin{array}{c}\mathbf{L o g} \mathbf{X}_{\mathbf{T}} \\
(\mathbf{m m})\end{array}$ & $\begin{array}{c}\mathbf{X}_{\mathbf{T}} \\
(\mathbf{m m})\end{array}$ \\
\hline 2 & & & 0.00 & 1.811 & 64.766 \\
5 & & & 0.84 & 1.928 & 85.646 \\
10 & 1.811 & 0.145 & 1.28 & 1.996 & 99.147 \\
25 & & & 1.71 & 2.058 & 114.396 \\
50 & & & 2.05 & 2.108 & 128.095 \\
\hline
\end{tabular}

\subsubsection{Distribusi Log Person III}

Tabel 7. Rekapitulasi Curah Hujan Rencana Metode Log Person III

\begin{tabular}{ccccccc}
\hline $\begin{array}{c}\mathbf{T} \\
(\mathbf{t a h u n})\end{array}$ & $\begin{array}{c}\mathbf{L o g} \overline{\mathbf{X}} \\
(\mathbf{m m})\end{array}$ & $\mathbf{S}$ & $\mathbf{C}_{\mathbf{s}}$ & $\mathbf{K}$ & $\begin{array}{c}\mathbf{L o g} \mathbf{X}_{\mathbf{T}} \\
(\mathbf{m m})\end{array}$ & $\begin{array}{c}\mathbf{X}_{\mathbf{T}} \\
(\mathbf{m m})\end{array}$ \\
\hline 2 & & & & $-0,0044$ & 1.811 & 64.672 \\
5 & & & & 0,8404 & 1.933 & 85.658 \\
10 & 1.811 & 0.145 & \multirow{2}{*}{0.0264} & 1,2845 & 1.997 & 99.296 \\
25 & & & & 1,7598 & 2.066 & 116.308 \\
50 & & & & 2,0652 & 2.110 & 128.746 \\
\hline
\end{tabular}

\subsubsection{Distribusi Gumbel}

Tabel 8. Rekapitulasi Curah Hujan Rencana Metode Gumbel

\begin{tabular}{cccccccc}
\hline $\begin{array}{c}\mathbf{T} \\
\text { (tahun) }\end{array}$ & $\mathbf{Y}_{\mathbf{T r}}$ & $\mathbf{S}_{\mathbf{n}}$ & $\mathbf{Y}_{\mathbf{n}}$ & $\mathbf{K}$ & $\mathbf{S}$ & $\begin{array}{c}\overline{\mathbf{X}} \\
(\mathbf{m m})\end{array}$ & $\begin{array}{c}\mathbf{X}_{\mathbf{T}} \\
(\mathbf{m m})\end{array}$ \\
\hline $\mathbf{2}$ & 0.3668 & & & -0.1431 & & & 64.928 \\
$\mathbf{5}$ & 1.5004 & & & 0.9677 & & & 90.179 \\
$\mathbf{1 0}$ & 2.2510 & 1.0206 & 0.5128 & 1.7031 & 22.7342 & 68.180 & 106.899 \\
$\mathbf{2 5}$ & 3.1993 & & & 2.6323 & & & 129.023 \\
$\mathbf{5 0}$ & 3.9028 & & & 3.3216 & & & 143.693 \\
\hline
\end{tabular}

\subsection{Analisis Uji Kesesuaian Distribusi Frekuensi}

Sebelum melakukan uji kesesuaian distribusi terlebih dahulu membandingkan nilai hitung pada parameter statistik dengan syaratsyarat yang ada berdasarkan tabel parameter statistik untuk menentukan jenis sebaran sebagai berikut pada tabel 9 .

Tabel 9. Perbandingan Syarat Distribusi dan Hasil Perhitungan

\begin{tabular}{ccccc}
\hline No. & Distribusi & Persyaratan & $\begin{array}{c}\text { Hasil } \\
\text { Perhitungan }\end{array}$ & Keterangan \\
\hline \multirow{2}{*}{ 1. } & \multirow{2}{*}{ Gumbel } & $\mathrm{C}_{s}=1.14$ & $\mathrm{C}_{s}=0.623$ & Tidak Memenuhi \\
& \multirow{2}{*}{ Normal } & $\mathrm{C}_{k}=5.40$ & $\mathrm{C}_{k}=3.386$ & Tidak Memenuhi \\
\hline \multirow{2}{*}{ 2. } & $\mathrm{C}_{s} \approx 0$ & $\mathrm{C}_{s}=0.623$ & Tidak Memenuhi \\
& & $\mathrm{C}_{k} \approx 3$ & $\mathrm{C}_{k}=3.386$ & Tidak Memenuhi \\
\hline
\end{tabular}




\begin{tabular}{ccccc}
\hline No. & Distribusi & Persyaratan & $\begin{array}{c}\text { Hasil } \\
\text { Perhitungan }\end{array}$ & Keterangan \\
\hline \multirow{2}{*}{ 3. } & Log Normal & $\mathrm{C}_{s}=\mathrm{C}_{v}{ }^{3}+3 \mathrm{C}_{v}=0.240$ & $\mathrm{C}_{s}=0.026$ & Tidak Memenuhi \\
& & $\mathrm{C}_{v}{ }^{8}+6 \mathrm{C}_{v}{ }^{6}+15 \mathrm{C}_{v}{ }^{4}+$ & $\mathrm{C}_{k}=2.789$ & Mendekati \\
\hline 4. & Log-Person III & Selain dari nilai diatas, $\mathrm{C}_{s} \neq 0$ & $\mathrm{C}_{s}=0.026$ & Memenuhi \\
\hline
\end{tabular}

Dari keempat metode yang digunakan di atas yang memenuhi persyaratan adalah sebaran log person III dengan nilai Cs $=0.026$ memenuhi persyaratan $\mathrm{C}_{s} \neq 0$. Dari sebaran yang telah memenuhi syarat tersebut perlu diuji kecocokan sebarannya dengan beberapa metode yaitu uji Chi-Kuadrat dan uji Smirnov-Kolmogorov. Hasil uji kecocokan sebaran menunjukkan distribusinya dapat diterima atau tidak. Berdasarkan pengujian data dengan uji Chi-Kuadrat dan uji Smirnov-Kolmogorov, maka didapatkan curah hujan yang terpilih yaitu curah hujan metode Log-Person III.

\subsection{Analisa Debit dan Dimensi Saluran Drainase Rencana}

Setelah menghitung nilai intensitas curah hujan, koefisien limpasan gabungan $\left(\mathrm{C}_{\mathrm{gab}}\right)$, dan memperoleh nilai luasan (A) dari hasil penggambaran AutoCad, selanjutnya menghitung debit rencana. Adapun nilai debit rencana dapat dilihat pada tabel 10.

Tabel 10. Rekapitulasi Debit Rencana pada Saluran Drainase

\begin{tabular}{ccccc}
\hline Saluran & $\begin{array}{c}\mathbf{I} \\
(\mathbf{m m} / \mathbf{j a m})\end{array}$ & $\mathbf{C}_{\text {gabungan }}$ & $\begin{array}{c}\mathbf{A}_{\text {total }} \\
\left(\mathbf{k m}^{\mathbf{2}}\right)\end{array}$ & $\begin{array}{c}\mathbf{Q} \\
(\mathbf{m} \mathbf{3} / \mathbf{d e t})\end{array}$ \\
\hline S1 & 125.6720 & 0.472 & 0.0605 & 0.9969 \\
S2 & 130.8715 & 0.335 & 0.0469 & 0.5712 \\
S3 & 158.5289 & 0.380 & 0.0618 & 1.0341 \\
S4 & 215.3338 & 0.302 & 0.0100 & 0.1806 \\
S5 & 115.4118 & 0.461 & 0.0717 & 1.0597 \\
\hline
\end{tabular}

Dari hasil perhitungan debit rencana yang ditunjukkan pada Tabel 10, bahwa debit terbesar yang masuk ke dalam saluran terjadi pada saluran S5 yaitu sebesar $1.0597 \mathrm{~m}^{3} / \mathrm{det}$, sedangkan yang terkecil terjadi pada saluran S2 yaitu $0.5712 \mathrm{~m}^{3} / \mathrm{det} . \mathrm{Dalam}$ perhitungan debit rencana yang dihasilkan berupa debit dari air hujan saja tanpa adanya tambahan dari debit air limbah masyarakat, hal tersebut dikarenakan dalam penelitian ini dirancang hanya memperhitungkan dari intensitas hujan saja tanpa adanya pengaruh dari limbah masyarakat di lokasi studi.

Bentuk saluran yang direncanakan adalah berbentuk trapesium, perencanaan dilakukan dengan menggunakan prinsip penampang ekonomis dengan analisis dimensi saluran drainase dapat dilihat pada tabel 11.

Tabel 11. Dimensi Saluran Drainase Rencana

\begin{tabular}{ccccccc}
\hline \multirow{2}{*}{ Saluran } & Tipe & $\begin{array}{c}\mathbf{Q} \\
\mathbf{3} / \mathbf{d e t})\end{array}$ & $\mathbf{S}$ & \multicolumn{3}{c}{ Dimensi Rencana } \\
\cline { 5 - 7 } & & & & $\mathbf{b}(\mathbf{m})$ & $\mathbf{h}(\mathbf{m})$ & $\mathbf{H}(\mathbf{m})$ \\
\hline S1 & Trapesium & 0.9969 & 0.0060 & 0.73 & 0.63 & 0.83 \\
S2 & Trapesium & 0.5712 & 0.0102 & 0.54 & 0.46 & 0.66 \\
S3 & Trapesium & 1.0341 & 0.0099 & 0.67 & 0.58 & 0.78 \\
S4 & Trapesium & 0.1806 & 0.0164 & 0.32 & 0.28 & 0.48 \\
S5 & Trapesium & 1.0597 & 0.0028 & 0.86 & 0.75 & 0.95 \\
\hline
\end{tabular}

Tabel 11 menunjukkan dimensi rencana saluran S1 - saluran S5 dengan dasar saluran (b) antara $0.32 \mathrm{~m}-0.86 \mathrm{~m}$, tinggi muka air $(\mathrm{h})$ berkisar antara $0.28 \mathrm{~m}-0.75 \mathrm{~m}$.

\subsection{Perbandingan Dimensi Saluran Drainase Rencana dan Saluran Drainase Eksisting}

Perbandingan dimensi saluran drainase rencana dan saluran drainase eksisting bertujuan untuk mengetahui wilayah-wilayah pada segmen tinjauan yang mempunyai kapasitas tampung yang tidak sesuai antara hasil analisis dengan fakta yang ada di lapangan, maka perlu adanya penanganan lebih lanjut terkait dengan permasalahan yang terjadi sehingga persoalan tidak berdampak pada masyarakat sekitar area genangan air. Adapun perbandingan nilai dimensi saluran rencana dan saluran drainase eksisting dapat dilihat pada tabel 12 . 
Tabel 12. Perbandingan Dimensi Saluran Rencana dan Eksisting

\begin{tabular}{|c|c|c|c|c|c|c|c|c|c|c|}
\hline \multirow[b]{2}{*}{ Saluran } & \multicolumn{5}{|c|}{ Rencana } & \multicolumn{4}{|c|}{ Eksisting } & \multirow[b]{2}{*}{ Ket. } \\
\hline & Tipe & $\begin{array}{c}\mathbf{b} \\
(\mathbf{m})\end{array}$ & $\begin{array}{c}\mathbf{h} \\
(\mathbf{m})\end{array}$ & $\begin{array}{c}\mathbf{H} \\
(\mathbf{m})\end{array}$ & $\begin{array}{c}\mathbf{A} \\
\left(\mathbf{m}^{2}\right)\end{array}$ & Tipe & $\begin{array}{c}\mathbf{b} \\
(\mathbf{m})\end{array}$ & $\begin{array}{c}\mathbf{H} \\
(\mathbf{m})\end{array}$ & $\begin{array}{c}\mathbf{A} \\
\left(\mathbf{m}^{2}\right)\end{array}$ & \\
\hline S1 & Trapesium & 0.73 & 0.63 & 0.83 & 0.6935 & Trapesium & 0.55 & 0.63 & 0.7321 & Aman \\
\hline $\mathrm{S} 2$ & Trapesium & 0.54 & 0.46 & 0.66 & 0.3744 & Trapesium & 0.61 & 0.67 & 0.8647 & Aman \\
\hline $\mathrm{S} 3$ & Trapesium & 0.67 & 0.58 & 0.78 & 0.5899 & Trapesium & 0.57 & 0.59 & 0.6776 & Aman \\
\hline $\mathrm{S} 4$ & Trapesium & 0.32 & 0.28 & 0.48 & 0.1320 & Trapesium & 0.89 & 0.51 & 0.7140 & Aman \\
\hline S5 & Trapesium & 0.86 & 0.75 & 0.95 & 0.9695 & Trapesium & 0.78 & 0.64 & 0.9006 & Tidak Aman \\
\hline
\end{tabular}

Tabel 12 menunjukkan terdapat saluran drainase yang masuk dalam kategori aman dan tidak aman, kategori aman menunjukkan bahwa luas penampang basah saluran drainase di lapangan/eksisting lebih besar dari luas penampang basah saluran drainase yang di rencanakan sedangkan kategori tidak aman di mana luas penampang basah saluran drainase di lapangan/eksisting lebih kecil dari luas penampang basah saluran yang direncanakan. Saluran S1 sampai dengan saluran S-4 masuk dalam kategori aman, hal ini ditunjukkan dengan nilai luasan (A) area rencana lebih kecil dibandingkan dengan luasan area eksisting. Sedangkan saluran S5 dalam kategori tidak aman karena nilai luasan rencana lebih besar daripada luas area eksisting.

\subsection{Faktor-faktor Penyebab Terjadinya Genangan}

Berdasarkan hasil peninjauan lokasi penelitian serta dengan adanya analisis kinerja saluran drainase, beberapa hal yang menjadi penyebab timbulnya genangan air pada wilayah studi antara lain:

1) Akibat kinerja saluran drainase

Salah satu penyebab terjadinya genangan pada titik tinjauan adalah kinerja saluran drainase eksisting yang tidak baik, hal tersebut ditunjukkan berdasarkan analisis dan tinjauan langsung ke lapangan bahwa kapasitas tampung saluran rencana lebih besar dibandingkan dengan kapasitas tampung saluran eksisting yang ada.

2) Akibat pola aliran drainase

Pola aliran drainase menjadi salah satu faktor yang terjadi di lokasi studi namun belum menimbulkan genangan air pada wilayah tersebut dikarenakan kapasitas tampung yang ada tidak besar. Pada saluran S3 pola aliran terputus dikarenakan drainase yang ada dibatasi oleh jalan dan tidak adanya gorong-gorong pada saluran tersebut sehingga air keluar dari saluran dan masuk ke badan jalan.

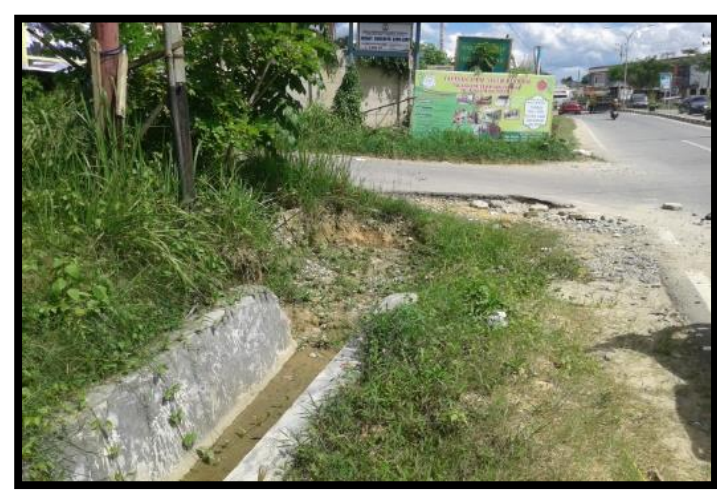

Gambar 3. Kondisi eksisting saluran S3

3) Akibat sistem gorong-gorong

Salah satu faktor yang menjadi penyebab terjadinya genangan air yaitu sistem gorong-gorong yang tidak bekerja dengan baik. Seperti tertimbun material batuan padat serta rerumputan yang menjalar. Saluran yang sistem gorong-gorongnya tidak bekerja dengan baik terjadi pada saluran S1, S2, S5. Namun saluran yang berefek besar yaitu pada saluran S5 dikarenakan sistem gorong-gorong yang ada di lokasi tertutup sehingga jalur air untuk mengalir terputus dan menimbulkan genangan air pada bahu jalan. 


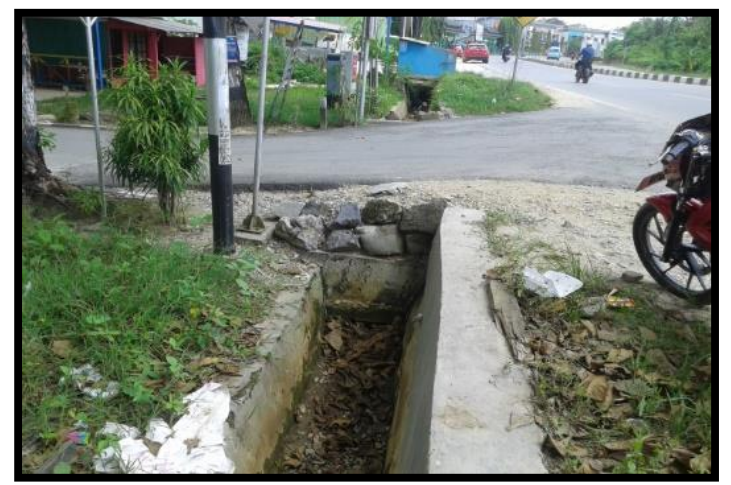

Gambar 4. Kondisi eksisting saluran S1

4) Akibat sedimentasi, sampah dan rerumputan

Permasalahan terkait sedimentasi, sampah dan rerumputan yang menjalar merupakan persoalan yang banyak terjadi di lokasi studi. Sedimentasi, sampah dan rerumputan yang menjalar pada dinding dan dasar saluran dapat menghambat laju air pada saluran yang ada dan berisiko besar menyebabkan terjadinya genangan air.

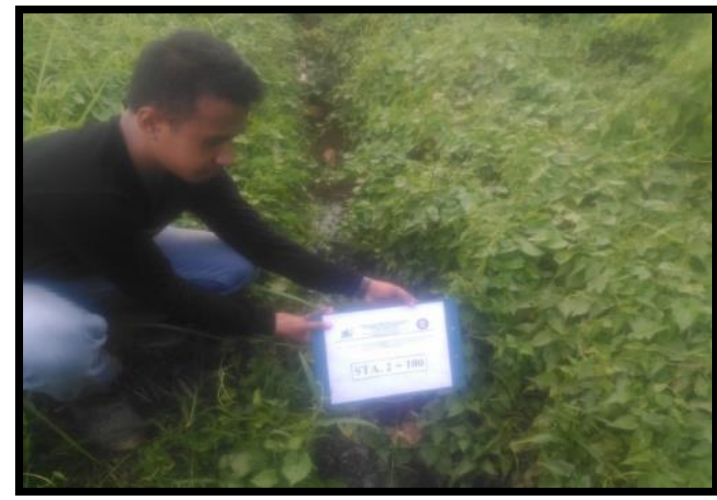

Gambar 5. Kondisi eksisting saluran S2

5) Akibat dimensi saluran yang rusak

Persoalan ini hanya terjadi di beberapa saluran saja di antaranya pada saluran S4. Pada saluran tersebut dimensi saluran yang ada di lapangan sudah tidak beraturan (rusak) baik dari keadaan dinding saluran maupun dasar saluran, hal tersebut menyebabkan saluran tidak dapat berfungsi dengan baik dalam penyaluran air limpasan yang ada sehingga lebih mudah menimbulkan genangan air pada ruas jalan.

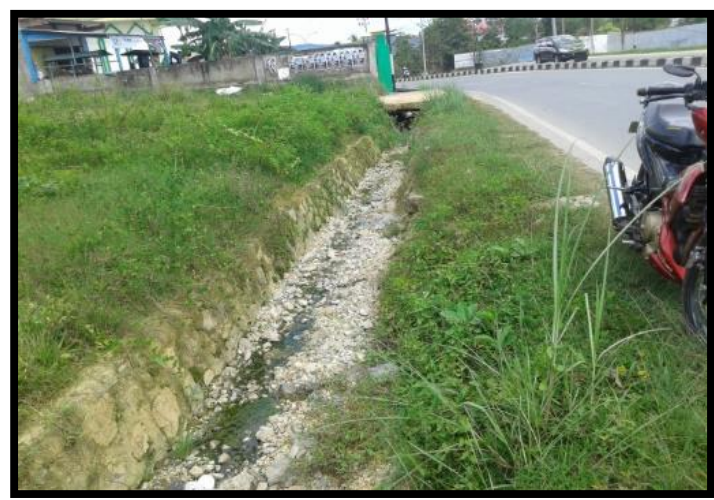

Gambar 6. Kondisi eksisting saluran S4

\section{KESIMPULAN DAN SARAN}

Berdasarkan hasil analisis dan pembahasan, maka dapat ditarik kesimpulan adalah sebagai berikut:

1. Berdasarkan hasil analisis kinerja saluran drainase didapatkan saluran drainase yang tidak aman yaitu: saluran S5. Dikarenakan luas penampang saluran yang direncanakan lebih besar dibandingkan luas penampang saluran yang ada di lapangan. 
2. Adapun beberapa faktor penyebab terjadinya genangan di beberapa segmen di lokasi studi antara lain, kinerja saluran, pola aliran, sistem gorong-gorong, sedimentasi, sampah, rerumputan menjalar dan dimensi saluran yang rusak. Penanganan dilakukan berdasarkan persoalan yang ada, dari segi kinerja saluran perlu di lakukan perubahan dimensi saluran, dari segi pola aliran perlu dilakukan pembentukan pola aliran yang baik dengan tidak membiarkan saluran terputus-putus, dari segi sedimentasi dan lain-lain perlu adanya normalisasi drainase secara berkala, dari segi dimensi saluran yang rusak perlu adanya perbaikan dimensi saluran.

Adapun saran yang dapat diberikan antara lain:

1. Perlu adanya penelitian lebih lanjut terkait dengan debit limbah masyarakat yang ada di lokasi tinjauan.

2. Normalisasi drainase secara berkala perlu dilakukan oleh pemerintah terkait, sehingga tidak menimbulkan adanya genangan air di beberapa titik pada wilayah lokasi tinjauan.

\section{DAFTAR PUSTAKA}

[1] N. H. P. Lubis dan B. O. Y. Marpaung, "Sistem Drainase di Koridor Jamin Ginting Pancur Batu Sumatera Utara," J. Koridor, vol. 9, no. 1, pp. 137-141, 2019.

[2] H. A. H. Hasmar, Drainasi Terapan. Yogyakarta: UII Press, 2011.

[3] A. M. Porajouw, T. Mananoma, and H. Tangkudung, “Analisis Sistem Drainase di Kelurahan Tikala Kumaraka Kota Manado," Sipil Statik, vol. 7, no. 12, pp. 1593-1604, 2019.

[4] Santi, Sulha, dan Muriadin, "Evaluasi Saluran Drainase Terhadap Genangan Air Pada Ruas Jalan Jend. A. H. Nasution Jalan Martandu (Studi Kasus: Bundaran Tank Kota Kendari)," STABILITA|| J. Ilm. Tek. Sipil, vol. 7, no. 2, pp. 197-206, 2019.

[5] M. Ikhsan dan T. Kadri, "Perbaikan Saluran Drainase Untuk Pengendalian Banjir Perumahan Metro Serpong, Tangerang," IPTEKSEN, no. September, pp. 51-56, 2019.

[6] BSN, “SNI 2415 : 2016 Tata Cara Perhitungan Debit Banjir rencana," 2016.

[7] Suripin, Sistem Drainase Perkotaan yang Berkelanjutan. Yogyakarta: Penerbit ANDI, 2004.

[8] Turyanto, Y. S. Sundari, dan A. Nur, "Perencanaan Saluran Drainase pada Perumahan Bumi Alam Indah Kebun Agung Kecamatan Samarinda Utara,” Kurva S J. Mhs., vol. 1, no. 1, pp. 533-548, 2018. 